\title{
Lasteaiaõpetajate hinnangud ja selgitused oma töö raskuse muutumisele: professionaliseerumine kui sümboolne kapital
}

\author{
Rain Mikser ${ }^{\text {a }}$, Marika Veisson ${ }^{a}$, Maire Tuul $^{\text {a }}$, Tiia Õun ${ }^{\text {al }}$, Kerstin Kööp ${ }^{a}$ \\ ${ }^{a}$ Tallinna Ülikooli haridusteaduste instituut
}

\begin{abstract}
Annotatsioon
Edendamaks alushariduse kvaliteeti ja kergendamaks lasteaiaõpetajate tööd, on Eestis ja mujal tõstetud õpetajate töö- ja haridusalaseid nõudeid. Lasteaiaõpetajad tunnustavad kõrgemaid nõudeid kui oma staatuse tõusu sümboleid, ent tajuvad samas, et lisanduvad kohustused muudavad töö üha raskemaks. Uurimuse eesmärk oli välja selgitada lasteaiaõpetajate hinnangud ja selgitused muutustele oma töö raskuse suhtes. Ankeetküsitlusele vastas 628 Eesti lasteaiaõpetajat, neist viieteistkümnega tehti hiljem individuaalne eluloointervjuu. Sõltumata staažist leidis enamik vastajaist, et töö on muutunud raskemaks, eelkõige lastesse, lapsevanematesse ning vahetusse töökorraldusse puutuvas. Samas väärtustasid vastajad oma ametinimetuse muutumist kasvatajast õpetajaks, erialaste haridusnõuete tõusu ning õppekavamuudatusi õpikäsituse ja õpetaja valikuvabaduse asjus. Lähtudes Pierre Bourdieu sümboolse kapitali teooriast, arutleme lasteaiaõpetajate professionaliseerumise võimaluste üle.
\end{abstract}

Võtmesõnad: professionaliseerumine, muutused, õpetaja, alusharidus

\section{Sissejuhatus}

Möödunud sajandi lõpukümnendeil alanud üleilmsed muutused õpetajate töös ja ettevalmistuses on mõjutanud ka lasteaiaõpetajaid. Sarnaselt kooliõpetajatega on nende tööd hakatud senisest enam riiklikult korraldama, tõusnud on lasteaiaõpetajate haridusnõuded, lisandunud riiklikud õppekavad ja õpetaja töö hindamise juhised, suurenenud on aruandekohustus väliste gruppide, eeskätt ametnike ja lapsevanemate ees (Bradbury, 2012; Neudorf, Ugaste, Tuul, \& Mikser, 2017; Oberhuemer, 2005). 
Lasteaiaõpetajate jaoks on muutustega kaasnenud aga uudne vastuolu, mida võib kirjeldada järgnevalt. Pikka aega on Eestis ja paljudes teistes maades lasteaiaõpetaja normtööaeg olnud pikem, palk väiksem ning erialane ettevalmistus lühem kui kooliõpetajatel (Katz \& Cain, 1988; Torm, 2011). Nagu Katz ja Cain samas mainivad, lisandus palgaga võrreldes väga suurele töömahule seetõttu ka kooliõpetajate omast madalam ühiskondlik staatus ja tööle omistatav kehvem maine. Seega on lasteaiaõpetaja töö nii koormuse poolest kui ka psühholoogiliselt (ehkki mitte tingimata intellektuaalselt) olnud suhteliselt raske (Katz \& Cain, 1988; Pruit, 2019). Kuna lasteaiaõpetaja töö on mitmel põhjusel muutunud ka vaimselt üha raskemaks (Bradbury, 2012; Brown, Weber, \& Yoon, 2015), on viimastel kümnenditel püütud seda tööd hõlbustada ja ametit köitvamaks muuta (Karila, 2012; Osgood, 2006). Selleks on peale korralduslike lahenduste (väiksemad rühmad ja normtööaeg, tugivõrgustiku arendamine) tõstetud lasteaiaõpetaja töö- ja haridusalaseid nõudeid, seda ühtaegu nii õpetajate avaliku staatuse ning seega ka enesehinnangu tõstmiseks kui ka igapäevatöö kergendamiseks. Viimast eesmärki kirjeldab Karila (2012, 586) järgmiselt: „[Lasteaiaõpetajate ülikoolipõhise ettevalmistuse] eesmärk on pakkuda kompetentse, mis aitavad professionaalil analüüsida muutuvat keskkonda ning lapsepõlveolusid. Lisaks pakub see sügavat teoreetilist teadmist, millele professionaal saab toetuda arendades institutsionaalset praktikat." Lasteaiaõpetajad aga, kes ühelt poolt on mõistagi huvitatud kõrgemast avalikust staatusest, näevad teiselt poolt selle saavutamise vahendeid oma professionaalsust piirava ning sageli tööd hoopis tarbetult raskendavana (Andrew, 2015; Bradbury, 2012; Jackson, 2017; Osgood, 2012). Vastuolulised tulemused lasteaiaõpetajate hinnangutes neile muutustele nähtuvad ka Eesti hiljutistest uurimustest (Mikser, Tuul, Veisson, \& Goodson, 2018; Mikser, Niglas, Tuul, Veisson, \& Goodson, 2019). Seetõttu tuleks teada, kuidas eesti lasteaiaõpetajad hindavad nende ametiajal toimunud muutusi töö raskuses ning kuidas nad neid muutusi selgitavad.

Artikli eesmärk on tutvustada Eesti lasteaiaõpetajate hinnanguid ja selgitusi töö raskuse muutumisele nende ametiajal, arutleda nende hinnangute ja selgituste võimalike põhjuste ja tagajärgede üle ning esitada ettepanekud edasiste uuringute ja alushariduspoliitika kohta. Artikli empiiriline andmestik põhineb lasteaiaõpetajatega korraldatud ankeetküsitlusel ja intervjuudel. Kaugem eesmärk, mille saavutamisse püüame panustada, on liigendada ja määratleda muutused nii, et tasakaalu saavutamine erilaadsete muutuste vahel oleks võimalikult lihtne ning alushariduspoliitiliste algatuste (näiteks õpetajate haridusnõuete edasise tõstmise) kestvam mõju oleks prognoositavam nii hariduspoliitikutele ja -ametnikele kui ka lasteaiaõpetajatele. 
Püstitasime järgmised uurimisküsimused.

1. Kuidas hindavad Eesti lasteaiaõpetajad oma ametiajal toimunud muutusi lasteaiaõpetaja töö raskuses? Täpsemalt uurisime, kas töö raskus on õpetajate hinnangul muutunud, ning kui see on muutunud, siis kas raskemaks või kergemaks.

2. Kuidas selgitavad Eesti lasteaiaõpetajad oma ametiaja jooksul toimunud muutusi lasteaiaõpetaja töö raskuses?

3. Millised üldised suundumused iseloomustavad lasteaiaõpetajate selgituste põhjal muutusi nende töö raskuses nende ametiajal? Vastus sellele küsimusele tähendab teatavat üldistust vastajate selgitustest.

4. Milliseid ohte ja võimalusi uurimistulemused võimaldavad täheldada lasteaiaõpetajate edasise professionaliseerumise seisukohalt?

Esmalt tutvustame artikli aluseks olevat professionalismi käsitust ja mõistestikku, mis pärineb prantsuse sotsioloogilt Pierre Bourdieult ning mida on edasi arendanud Willem Schinkel ja Mirko Noordegraaf. Seejärel käsitleme viimaste kümnendite muutusi lasteaiaõpetajate professionaliseerumises teistes maades ja Eestis. Peatume vastuoludel, mille tõttu on vaja tunda lasteaiaõpetajate hinnanguid töö raskuse muutumisele. Seejärel tutvustame uuringu metoodikat ja tulemusi ning esitame neile tuginevad järeldused ja ettepanekud.

\section{Bourdieu professionalismi käsitus ning Schinkeli ja Noordegraafi edasiarendus}

Õpetaja professionalismi määratlusi ja liigendusi on palju ning need rõhutavad õpetaja töö eri tahke. Tänini viidatakse sageli valdkonna klassiku Eric Hoyle’i seisukohale, et õpetaja professionalismi mõiste, vaatamata ohtrale kasutusele, „trotsib ühtset kokkulepet oma tähenduse suhtes" (Brock, 2014, lk 66; Locke, Vulliamy, Webb, \& Hill, 2005, lk 558; Tight, 2002, lk 86). Kuna keskendume lasteaiaõpetajate ametiajal toimunud muutustele, millest paljud hõlmavad haridust ja ühiskonda tervikuna, on asjakohane selline professionalismi käsitus, mis võimaldab arvestada alushariduse eripärast arengulugu võrreldes teiste haridusastmetega. Sellise käsituse on esitanud Schinkel ja Noordegraaf (2011). Nad tuginevad prantsuse sotsioloogi Bourdieu refleksiivsele sotsioloogiale (Bourdieu \& Wacquant, 1992) ning tema sümboolse kapitali teooriale. Schinkel ja Noordegraaf märgivad, et Bourdieu kasutas professionalismi mõistet harva ja hajusalt - osalt seetõttu, et mõiste ei ole prantsuse keeleruumis kuigi levinud. Samas arvustas ta seda teravalt ning soovitas sellest loobuda (Bourdieu \& Wacquant, 1992, lk 242). Seega ei saa rääkida „Bourdieu professionalismi teooriast“, vaid Schinkeli ja Noordegraafi professionalismi käsitusest Bourdieu algse, suhteliselt viimistlemata käsituse alusel. 
Selleks aluseks, millel Schinkel ja Noordegraaf (2011) eristavad Bourdieu ja samuti iseendi käsitust enamikust professionalismi käsitustest ${ }^{2}$, on Bourdieu rõhuasetus professiooni mõiste sisu ühiskondlikule päritolule ning professioonide vastastikusele suhtelisusele ja ajaloolisele muutumisele - samal ajal kui enamik käsitusi võtab professioone ja nende suhteid otsekui loomulike, etteantutena. Schinkel ja Noordegraaf jätkavad, et Bourdieu järgi on professioonide ja nende vastastikuste suhete hetkeolukord alati teatava ajaloolise võimuvõitluse tulemus. Nad osundavad Bourdieule:

„Professioon“ on rahvakeelne mõiste, mis on kritikavabalt sokutatud teaduskeelde ning mis toob endaga kaasa kogu ühiskondliku ebateadlikkuse. See on teatud rühma ja rühmade esinduste ajalooliselt loodud ühiskondlik toode, mis on salaja lipsanud selle rühma teaduslikku mõtlemisse (Bourdieu \& Wacquant, 1992, lk 242-243, viidatud Schinkel \& Noordegraaf, 2011, lk 72 j).

Eelnev tsitaat väljendab Bourdieu sotsioloogia refleksiivsust: see eeldab ühiskonnateadlaselt ühiskonnaelu suhtelisuse tajumist - seda, et käibemõisteid ei saa kriitikavabalt teaduskeeles kasutada, kuna need on ühiskondlike protsesside tulemused, mitte seletused neile protsessidele (Schinkel \& Noordegraaf, 2011). Mõistmaks professioonide kujunemist, tuleb uurijal Bourdieu järgi taanduda "professiooni“ kui käibemõiste kasutamisest ning leida ise sobivad ühikud professionalismi kujunemise uurimiseks (Bourdieu \& Wacquant, 1992, lk 243; Schinkel \& Noordegraaf, samas). Schinkel ja Noordegraaf rõhutavad, et "professioon“ on Bourdieu järgi võimusuhet märkiv mõiste, mida väljendab ka levinud eristus „päris-“ ja „poolprofessioonide“ vahel ning paljude nn töölisklassi ametite mittetunnustamine professioonidena. Erinevused, mis algselt on üksnes suvalised punktid jaotamatus järjepidevuses, saavad aja jooksul ühiskondlikult pühitsetud „eristusteks ${ }^{\text {‘3 }}$ (Bourdieu, 1996; viidatud Schinkel \& Noordegraaf, 2011, lk 76 j).

Põhjus, miks ühiskonnarühmad võitlevad omavahel professionalismi ja professioonide teatud viisil määratlemise eest, on Schinkeli ja Noordegraafi sõnul nähtuses, mida Bourdieu nimetab sümboolseks kapitaliks. Algselt eristas Bourdieu majanduslikku, sotsiaalset ja kultuurilist kapitali. Neist esimene märgib isiku või isikute rühma omatavaid materiaalseid väärtusi, teine suhete võrgustikku, aunimetusi ja volitusi ning kolmas haridustasemeid ja kutsetunnistusi (Noordegraaf \& Schinkel, 2011; Schinkel \& Noordegraaf, 2011).

Schinkel ja Noordegraaf esitavad selle enamiku näidetena A. Abbotti ja M. S. Larsoni käsitused.

3 Jutumärgid originaalis. 
Sümboolne kapital on staatusel põhinev kapital mingis eluvaldkonnas, teatav põiming eelnevatest, eelkõige sotsiaalsest ja kultuurilisest kapitalist (Bourdieu, 1993; Schinkel \& Noordegraaf, 2011; vt ka Jackson, 2017, lk 798). Eesti teadlastest määratleb Raud (2013, lk 447) sümboolset kapitali järgmiselt: „Bourdieu teoorias kujutletav ressurss, mis võimaldab tõsta enesega seotud kultuurinähtuste väärtust“. Schinkel ja Noordegraaf (2011) märgivad, et sümboolne kapital põhineb haridusvaldkonnas eelkõige kultuurilisel kapitalil, kuigi see ei ole nii kõigis valdkondades, näiteks majanduses. Seal sõltub isiku staatus peale hariduse paljudest muudest teguritest, mõnikord pole haridus neist sugugi peamine. Haridusvaldkonnas sõltub staatus aga üsna otseselt isiku haridustasemest või teaduskraadist.

Erinevalt teistest kapitali liikidest on sümboolne kapital põhimõtteliselt elitaarne nähtus (Schinkel \& Noordegraaf, 2011). See tähendab, et kui aineliste ja vaimsete väärtuste lisandumisel ühiskonda võib muu kapitali ning nende kandjate hulk suureneda, siis sümboolset kapitali on alati vaid piiratud hulgal inimestel - nagu spordivõistlustel on auhinnalisi kohti vaid teatud arv, sõltumata teiste võistlejate tulemustest. Just seetõttu on sümboolne kapital alati suhteline ehk ilmneb üksnes võrdluses teistega; just seetõttu on see võimuvõitluse aines; just seetõttu on see ajalooline, kuna võimuvõitlus eri valdkondade vahel ning nende sees on pidev ja selle tulemused alati vaid ajutised. Just seepärast peavad Schinkel ja Noordegraaf (2011), eristades enda seisukohta siin Bourdieu omast, vajalikuks säilitada professionalismi mõistet kui analüütilist vahendit: nimelt Bourdieu esiletoodud asjaolul, et mõistmaks selle aluseks olevaid protsesse ja võimuvõitlusi, tuleb professionalismi ja professioonide arengut vaadelda nende ajaloolises arengus ja vastastikuses seoses. Nad teevad ettepaneku:

Vahest peaksime käsitlema professionalismi kui dünaamilist mõistet, pigem tegusõna kui nimisõnana - „professionaliseerumine ${ }^{4 “}$ - ning mitte kui staatilist mõistet üleüldiste, kindlaks määratud ja kõikjal kehtivate tunnustega. Kuigi mõiste on vältimatult seotud teadmiste, asjatundlikkuse, ühenduste, välistuste, staatuse, hariduse, standardite ja eeskirjadega ning see täidab teatud organisatsioonilisi, ühiskondlikke ja ideoloogilisi eesmärke, kogevad muutuvad ühiskonnad ometi pidevat professionalismi ümbertöötamist. See tähendab, nad kogevad protsesse, milles professionalismi aated üle vaadatakse (Schinkel \& Noordegraaf, 2011, lk 83-84).

4 Grammatiliselt on siiski tegemist nimisõnaga, nagu ka ingliskeelses originaalis (professionalization). 
Professionalism on Schinkeli ja Noordegraafi (2011) järgi sümboolse kapitali vorm, staatuse märk võrreldes teiste valdkondadega ning võrreldes teiste inimestega samas valdkonnas. Professionalism kui sümboolne kapital võimaldab teatud valdkonnal saavutada teiste valdkondade tunnustuse, ent ka võrrelda professiooni esindajaid omavahel (Schinkel \& Noordegraaf, 2011). Hariduse valdkonnas on professioonisisese sümboolse kapitali nimel toimuva võitluse näiteks Eestis praeguseks kaotatud õpetajate ametijärgud, ent ka üha olulisemaks muutuvad teadustöö tulemuste näitajad akadeemilistel ametikohtadel.

Professionaliseerumine kui sümboolse kapitali ümberjagamise protsess Schinkeli ja Noordegraafi eelviidatud tähenduses on keskseks mõisteks ka meie artiklis. Järgnev ülevaade lasteaiaõpetajate kui professiooni kujunemisest on otseselt seotud Bourdieu ning Schinkeli ja Noordegraafi käsitusega professionaliseerumisest kui ajaloolisest protsessist, millel on lasteaiaõpetajatele eriline tähendus.

\section{Lasteaiaõpetajate professionaliseerumine Bourdieu ja Schinkeli-Noordergraafi käsituste valguses}

Viimastel kümnenditel on lasteaiaõpetajad paljudes maades professionaliseerunud sarnaselt kooliõpetajatega. Seda arengut on toetanud ka avaliku arusaama muutumine (Neudorf et al., 2017). Ajalooliselt on aga eri haridusastmete õpetajate ettevalmistust ja tööpraktikat nähtud väga erinevana (Katz \& Cain, 1988). Paljudes Euroopa maades sõltus õpetajate erialase ettevalmistuse kestus, tase ja sisu kuni 20. sajandi kolmanda veerandini tugevalt haridusastmest, kuhu tulevane õpetaja tööle siirdus: see oli keskkooliõpetajatele ülikoolipõhine ja suunatud põhjalike ainealaste teadmiste omandamisele, samas madalamate haridusastmete õpetajaid koolitati ülikoolidest eraldiseisvates seminarides ning koolitus ületas harva teadmiste ja oskuste edastamiseks hädavajalikku mahtu ning taset (Judge, 1998). Katz ja Cain märkisid aastakümnete eest:

Üks vähestest tõeliselt usaldusväärsetest üldistustest [alushariduse] valdkonna ja selle õpetajate kohta on, et mida noorem on õpetatav laps, seda lühem on tema õpetaja ettevalmistus, madalam tema staatus, kesisem tema tööle omistatav maine, väiksem töö tegemiseks nõutav kvalifikatsioon, madalam tema palk ning pikemad tema töötunnid (Katz \& Cain, 1988, lk 1487).

Seega on lasteaiaõpetajate professionaliseerumine olnud vaevaline protsess, väljakujunenud võimusuhete ja arusaamade ületamine (Persson \& Tallberg Broman, 2015). 
Lasteaiaõpetajate professionaliseerumine Bourdieu ning SchinkeliNoordegraafi käsituse alusel tähendab, et on saavutatud kooliõpetajate omadega sarnased haridusnõuded ehk üldjuhul kõrgharidus (Gunnarsdottir, 2014; Oberhuemer, Schreyer, \& Neuman, 2010; Ryan \& Gibson, 2016). Samuti on üha enam riiklikult korraldatud alusharidusasutuste tegevus, kehtestades riiklikke õppekavu ning hinnates laste õpi- ja arengutulemusi (Neudorf et al., 2017). Nende muutuste aluseks on tugevnenud arusaam alushariduse tähtsusest ning selle väljendumine Euroopa Komisjoni, UNESCO ja teiste rahvusvaheliste ühenduste tegevuspõhimõtetes: alusharidus on laiapõhjaline, terviklik ning toetab laste tasakaalustatud õpetamist, kasvatamist ja arendamist (Van Laere, Peeters, \& Vandenbroeck, 2012; Neudorf et al., 2017). Võib seega öelda, et võrreldes Katzi ja Caini kirjeldatud kümnenditetaguse olukorraga on alushariduse esindajate võitlus professionaliseerumise kui sümboolse kapitali eest olnud edukas: nende tööd ja ametit tunnustatakse võrdselt kooliõpetajatega.

Teisalt tuleneb alushariduse arenguloost ja lasteaiaõpetajate kogemustest põhjusi, miks osa lasteaiaõpetajaid ei toeta nimetatud algatusi, isegi kui need pakuvad kooliópetajatega võrdset sümboolset kapitali. Ajalooliselt on eriti Põhja- ja Kesk-Euroopas levinud nn sotsiaalpedagoogiline lähenemine, mille puhul on lasteaiaõpetajal tähtis ülesanne õpetamise kõrval olla kõlbeline eeskuju ning lasteaia, perekonna ja kohaliku kogukonna vahendaja (Broström, 2017; Clausen, 2015). Koos professionaliseerumise teiste tunnustega ilmneb viimastel kümnenditel aga alushariduse koolistumine ehk üha suurem sarnasus üldhariduskooliga (Neudorf et al., 2017). Keskendumine laste koolivalmidusele ähvardab jätta sotsiaalpedagoogilise lähenemise tagaplaanile ning asetab lasteaiaõpetaja ettevalmistuse sisu liigsesse sõltuvusse ülikoolide eelistustest (Johansson, 2006; Karlsson Lohmander, 2015). Samas tõuseb lasteaiaõpetajate aruandekohustus nii haridusametnike kui ka lastevanemate ees (Bradbury, 2012; Vlasov \& Hujala, 2016) ning suureneb laste isiklike, kultuuriliste ja keeleliste erivajaduste hulk (Brown et al., 2015). Brown jt (samas, lk 3-4) väljendavad neid muutusi järgmiselt: „Lasteaiaõpetajailt oodatakse üha kirjuma kultuuri- ja keeletaustaga lastele standardiseeritud teadmiste ja oskuste õpetamist, et laste akadeemilised saavutused vastaksid poliitikute nõudmistele“.

Eelnevaga seotud, eelkõige ingliskeelsetes maades väljendatud probleemiks seoses töö- ja haridusalaste nõuete tõstmisega on selle vähene vahetusväärtus (Osgood, 2012). Paljude lasteaiaõpetajate hinnangul ei kajastu professionaliseerumine kuidagi nende majandusliku kapitali või staatuse tõusus (Andrew, 2015; Jackson, 2017; Osgood, 2012; Payler \& Locke, 2013). Inglise uurija Osgood (2012, lk 143) osundab vestlusele ühe lasteaiaõpetajaga: 
... kus on ajend? Sa võid panustada aastaid ja ma olen siin näinud inimesi seda tegemas, kes tegelikult tapavad ennast, et saada seda kraadi - milleks? Palk on sama, töö on sama, ja enne kui sa sellest aru saad, oled kulutanud viimased viis või kümme aastat või kaua iganes selle paberitüki saamisele, ennast lihtsalt kohusetundest ribadeks tõmmates.

Osa autoreid märgib, et töö- ja haridusnõuete tõstmine võib koguni vastanduda lasteaiaõpetaja arusaamale enesest kui juba niigi heade oskuste ja hoiakutega professionaalist, mistõttu nõuete tõstmine on talle solvav (Andrew, 2015; Payler \& Locke, 2013). Payler ja Locke (2013, lk 133) näitlikustavad eelöeldut väljavõttega lasteaiaõpetaja intervjuust: „See [haridusnõuete tõstmine] kahjustab inimesi, kes on suurepärased selles, mida nad teevad, nimelt seetõttu, et nad on need, kes nad on.“

Bourdieu ning Schinkeli ja Noordegraafi käsitusele tuginedes on lasteaiaõpetajate haridusnõudeid käsitlenud Austraalia uurija Jackson (2017). Ta viitab Bourdieu mõistele sümboolne vägivald, mida Bourdieu määratleb kui „vägivalda, mida rakendatakse ühiskondliku esindaja suhtes tema kaasosalusel" (Bourdieu \& Wacquant, 1992, lk 167; Jackson 2017, lk 801). Raud (2013, lk 447) määratleb sümboolset vägivalda kui „Bourdieu teoorias parasjagu sümboolse võimu juures oleva rühma õigust oma arusaama kultuurist kõigile peale suruda“. Sümboolse vägivalla ohvriks langevad Jacksoni sõnul lasteaiaõpetajad, kes keelduvad tunnustamast kõrgemaid haridusnõudeid kui sümboolse kapitali omandamise viisi ning jätkavad tööd kõrgema haridusega ametikaaslastest madalamal ametikohal. Ka Eesti ajakirjandus on kajastanud selliseid sümboolse vägivalla juhtumeid lasteaiaõpetajatega (Vapper 2015).

Kirjeldatud vastuolust nähtub, et lasteaiaõpetajad on professionaliseerudes sattunud kahe vastandliku suundumuse vahele: ühelt poolt on tõusvad töö- ja haridusnõuded tõstnud nende sümboolse kapitali kooliõpetajate omaga võrreldavale tasemele. Teisalt vastanduvad need positiivsed arengud lasteaiaõpetajate ajaloolisele enesemääratlusele ega pruugi kajastuda nende töö kergemaks muutumises.

\section{Lasteaiaõpetajate professionaliseerumine Eestis}

Eesti kuulub riikide hulka, milles alusharidust käsitletakse ühtse tervikuna, samuti on üle riigi lasteaiaõpetajate haridusnõuded ühtlustatud (Mikser et al., 2018). Seega ei tulene Eestis alushariduse ülesehitusest valdkonnasiseseid eeldusi sümboolse kapitali ebavõrdseks jaotuseks. See kehtib ka kogu ajajärgu kohta pärast Teist maailmasõda, mil alusharidust hakati Eestis riiklikult reguleerima (Veisson \& Mikser, 2013). 
Nõukogude ajal oli alusharidus riiklikult tähtis eelkõige naiste suure tööhõive tõttu. Samas oli lasteaiaõpetajate - toonase nimetusega kasvatajate erialane ettevalmistus võrreldes kooliõpetajatega tagasihoidlik, kuna töötati üleliiduliste üksikasjalike programmide alusel, mida kohandati Eesti oludele vaid vähesel määral (Neudorf et al., 2017). Ehkki kõrgharidusega lasteaiaõpetajaid hakati Eestis ette valmistama juba 1967. aastal (Veisson, 2017), sai kõrgharidus lasteaiaõpetajatele kohustuslikuks alles 2013. aastal (Mikser et al., 2018). Eelkirjeldatud rahvusvahelisele praktikale tunnuslikult kehtestati taasiseseisvunud Eestis ka alusharidusasutuste riiklik õppekava hiljem kui üldhariduskoolide riiklik õppekava: 1996. aastal üldhariduskoolidele ning 1999. aastal lasteaedadele (Ruus \& Mikser, 2013).

\section{Metoodika}

\section{Andmekogumismeetod}

Artiklis tutvustatavad tulemused pärinevad kaheosalisest uuringust: ankeetküsitlusest ja intervjuudest nende ankeetküsitlusele vastanutega, kes avaldasid selleks nõusolekut. Ankeetküsitluse üldeesmärk oli selgitada õpetajate arusaamu heast õpetajast ja tema ettevalmistusest ning sellest, kuidas õpetaja töö ja nõuded sellele on vastajate ametiajal muutunud. Ankeedi koostas rühm, mis koosnes üld- ja alusharidusastme õpetajaid uurivatest akadeemilistest töötajatest ja doktorantidest. Lasteaiaõpetajate ankeedis oli kokku 46 küsimust, sealhulgas vastajate sotsiodemograafilisi andmeid käsitlevad küsimused. Siinne artikkel keskendub lasteaiaõpetajatele esitatud küsimusele: „Kas ja mil määral on Teie ametiaja jooksul muutunud õpetajatöö raskus/keerukus Eestis?“ Palusime vastajatel teha märge sobivaimale viie vastusevariandi seast: 1) töö on muutunud oluliselt raskemaks; 2) töö on muutunud mõnevõrra raskemaks; 3) töö raskus ei ole muutunud; 4) töö on muutunud mõnevõrra kergemaks; 5) töö on muutunud oluliselt kergemaks. Juhul kui vastaja pidas töö raskust muutunuks, palusime küsimuse järel olevatel ridadel vabas vormis lisada muutuste lühiselgitus.

Intervjuud selleks nõusoleku andnud vastajatega tegime Goodsoni (2013) narratiivse eluloointervjuu metoodika alusel, mille puhul eriti intervjuu algupoolel võimalikult välditakse otseselt suunavaid küsimusi ning lastakse vastajal enesel avada asjaolud, mis tema töö- ja isiklikku elu on kujundanud. Seejärel palub uurija lisaselgitusi intervjuu käigus või muul viisil (meie puhul ankeetküsitluse põhjal) vastaja väljendatud kirjelduste, hinnangute ja arusaamade kohta, mis on uurimisküsimuse seisukohalt olulised. 


\section{Valim ja uurimisprotseduur}

Ankeetküsitluse valimi moodustamiseks järjestasime kõik eesti õppekeelega lasteaiad HaridusSilma (2015) andmebaasist saadud laste arvu järgi ning valisime välja iga viienda üle 60 lapsega lasteaia. Võtsime ühendust valitud lasteaedade juhtkonnaga, et küsida luba neis uuringu korraldamiseks. Seejärel edastasime lasteaia juhtkonna või alushariduse eriala üliõpilaste abil õpetajatele paberil tagastusümbrikus oleva ankeedi ning vastamise vabatahtlikkust, vastaja anonüümsust ja andmete säilitamist ning töötlemist selgitava kaaskirja. Kokku saatsime 1000 ankeeti. Täidetuna tagastati 653. Küsimusele õpetajatöö raskuse muutumise kohta vastas $96 \%$ ehk 628 õpetajat (edaspidi ka: vastanud). Neist 420 ehk 66,9\% lisas vabavastuselise selgituse. Enam kui poolel vastanuist oli pedagoogiline kõrgharidus (56,8\%), neljandikul (26,8\%) pedagoogiline keskeriharidus ning seitsmendikul (14,5\%) muu haridus. 12 õpetajat $(1,9 \%)$ ei märkinud oma haridustaset. Enamik vastanuist $(89,8 \%)$ töötas lasteaias täiskoormusega. Rühmaõpetajaid oli vastanute seas $88,7 \%$, muusika- ja/või liikumisõpetajaid 6,8\% ning muid õpetajaid 2,7\%. Oma ameti jättis märkimata 11 vastanut $(1,8 \%)$. Esindatud olid kõik maakonnad, enim vastajaid oli Harju(41,6\%), Tartu- (11,3\%) ja Pärnumaalt (10,2\%). Kaks kolmandikku (67,8\%) vastanutest elasid linnas ja kolmandik $(32,2 \%)$ maal, mis ligikaudu vastab Eesti elanikkonna proportsioonidele. Vastanute vanus jäi 19-70 aasta vahele, keskmiselt oli see 44,1 aastat. Vastanute staaž jäi 1-50 aasta vahele, keskmiselt oli see 18,7 aastat. Kolm vastanut olid meesõpetajad.

Ankeedis väljendas nõusolekut järgneva intervjuuga 58 õpetajat. Kuna soovisime teada ankeedis esitatud hinnangute selgitusi võimalikult pika aja kohta, valisime intervjueeritavateks üksnes vastajad, kes olid töötanud lasteaiaõpetajana (varem kasvatajana) ka nõukogude ajal. Oma kontaktandmed oli ankeeti lisanud 29 sellele tingimusele vastavat õpetajat. Neist viieteistkümnega õnnestus kontakti saada ja intervjuu teha. Kümme neist oli kõrgharidusega ja viis keskeriharidusega. Üks kõrgharidusega vastaja oli lõpetanud kehakultuuri eriala ja hiljem osalenud 160-tunnisel alushariduse täienduskursusel. Üks keskeriharidusega vastaja oli lõpetanud pedagoogilise seminari koolieelse pedagoogika eriala ja töötas lasteaia muusikaõpetajana. Intervjueeritavate keskmine vanus oli 57 aastat ja õpetajastaaži keskmiselt 34 aastat. Intervjueeritavad olid pärit eri maakondadest. Intervjuud peeti sõltuvalt vastaja soovist kas tema lasteaias või Tallinna Ülikoolis. Intervjuu kestis keskmiselt üks tund ja kaks minutit. 


\section{Andmeanalüïs}

Valimi kirjeldamiseks kasutasime andmete koondamist ja kirjeldava statistika meetodeid (protsentanalüüs, miinimumi ja maksimumi leidmine, aritmeetilise keskmise arvutamine). Kuna eeldatavasti on eri ajajärkude muutustel õpetaja tööle erinev mõju, jaotasime ankeediküsimuse vastuste analüüsimisel vastajad esmalt staaži alusel kolme rühma; (1) kuni 8 aastat - töötanud vaid praegu kehtiva koolieelse lasteasutuse riikliku óppekava alusel; (2) 9-24 aastat - tööle asunud pärast Eesti taasiseseisvumist; (3) 25 ja rohkem aastat - töötanud nii nõukogude ajal kui ka pärast seda. Seejärel esitasime nende protsentuaalse jaotumise antud vastuste põhjal (vt tabel 1).

Ankeediküsimuse vabavastuseid analüüsisime kahes osas. Esmalt koondasime nende õpetajate vastused, kelle hinnangul on töö nende ametiajal kas mõnevõrra või oluliselt raskemaks muutunud, ning tõime tavapärast kvalitatiivset sisuanalüüsi (Hsieh \& Shannon, 2005) kasutades välja olulisemad töö raskust muutnud tegurid. Seejärel tegime sama nende õpetajate vastustega, kelle hinnangul on töö mõnevõrra või oluliselt kergemaks muutunud. Vabavastuste analüüsimiseks kasutasime avatud kodeerimist ning intervjuutekstide analüüsimiseks nii avatud kui ka suunatud kodeerimist: esmalt analüüsis üks uurija avatud kodeerimise abil ankeetide vabavastuseid ja teine intervjuutekste, seejärel võrreldi tekkinud koode ja kategooriaid ning kitsendati edasist intervjuude analüüsi lähtuvalt uurimisküsimustest ja ankeedis esile tõusnud kategooriatest. Viimased võeti intervjuutekste analüüsides aluseks seetõttu, et ankeedile vastanud olid oma taustalt erinevamad ning nende vastused varieerusid artikli kesksetel teemadel rohkem kui intervjuuvastused.

Tekste analüüsis kolm uurijat, kes esialgse kodeerimise järel (üks analüüsis ankeedi vabavastuseid, teine intervjuusid ning kolmas mõlemaid) ühistes aruteludes jõudsid lõplike koodide ja kategooriateni. Arvulistest tulemustest olulisemaks pidasime ankeediküsimuse vabavastustes ja intervjuudes ilmnevaid uurimisküsimuste seisukohast olulisi tähendusi.

\section{Tulemused}

Lasteaiaõpetajate vastused ankeediküsimusele: „Kas ja mil määral on Teie ametiaja jooksul muutunud ópetajatöö raskus/keerukus Eestis?"“ on esitatud tabelis 1 . 
Tabel 1. Vastajate hinnangud töö raskuse muutumisele nende ametiajal

\begin{tabular}{|c|c|c|c|c|c|}
\hline \multirow{2}{*}{\multicolumn{2}{|c|}{ Tööaja jooksul on õpetajatöö... }} & \multicolumn{3}{|c|}{ Vastajate ametialane staaž } & \multirow{3}{*}{$\begin{array}{r}\text { Kogu } \\
\text { valim } \\
197\end{array}$} \\
\hline & & \multirow{2}{*}{$\begin{array}{c}\text { kuni } 8 \text { a } \\
38\end{array}$} & \multirow{2}{*}{$\begin{array}{c}9-24 a \\
58\end{array}$} & \multirow{2}{*}{$\begin{array}{c}\text { üle } 24 \text { a } \\
101\end{array}$} & \\
\hline 1) muutunud oluliselt & Arv & & & & \\
\hline raskemaks & Protsent & 22,9 & 34,3 & 34,5 & 31,4 \\
\hline \multirow{2}{*}{$\begin{array}{l}\text { 2) muutunud mõnevõrra } \\
\text { raskemaks }\end{array}$} & Arv & 77 & 72 & 118 & 267 \\
\hline & Protsent & 46,4 & 42,6 & 40,3 & 42,5 \\
\hline \multirow{2}{*}{$\begin{array}{l}\text { 3) raskus on jäänud } \\
\text { samaks }\end{array}$} & Arv & 44 & 32 & 57 & 133 \\
\hline & Protsent & 26,5 & 18,9 & 19,5 & 21,2 \\
\hline \multirow{2}{*}{$\begin{array}{l}\text { 4) muutunud veidi } \\
\text { kergemaks }\end{array}$} & Arv & 5 & 6 & 13 & 24 \\
\hline & Protsent & 3 & 3,6 & 4,4 & 3,8 \\
\hline \multirow{2}{*}{$\begin{array}{l}\text { 5) muutunud tunduvalt } \\
\text { kergemaks }\end{array}$} & Arv & 2 & 1 & 4 & 7 \\
\hline & Protsent & 1,2 & 0,6 & 1,4 & 1,1 \\
\hline \multirow[t]{2}{*}{ Kokku } & Arv & 166 & 169 & 293 & 628 \\
\hline & Protsent & 100 & 100 & 100 & 100 \\
\hline
\end{tabular}

Ligikaudu kolmveerand vastajaist leidis, et õpetajatöö on muutunud raskemaks. Viiendiku vastajate hinnangul ei ole töö raskus muutunud ning 5\% vastas, et töö on muutunud kergemaks. Kuigi kuni kaheksa-aastase staažiga õpetajate hulgas oli võrreldes staažikamate õpetajatega rohkem neid, kelle hinnangul on töö raskus jäänud samaks, leidis suurem osa (69,3\%) neist siiski, et võrreldes nende tööle asumise ajaga on töö muutunud kas mõnevõrra või oluliselt raskemaks.

Ankeediküsimuse vabavastuses tõusid kõigis staažirühmades esile kolm kategooriat, mida nähti peamiste põhjustena õpetajatöö raskemaks muutumisel: lastega, lastevanematega ja töökorraldusega seotud muutused. Lisaks tõusid üle kaheksa-aastase staažiga õpetajate vabavastustes ja intervjuudes esile ka muutused seadustikus, õppekavades ning õpikäsituses. Järgnevates alapeatükkides anname lühiülevaate õpetajate selgitustest nendes neljas teemavaldkonnas.

\section{Lastega seotud muutused}

Olenemata staažist selgitasid vastajad töö raskemaks muutumist lastega seotult: rühmas on rohkem lapsi, tavarühmas rohkem erivajadustega lapsi. Staažikas õpetaja selgitas intervjuus: 
Praegu pannakse hästi palju erivajadustega lapsi tavarühma. Ma olen selle poolt, et need erivajadustega lapsed peavad harjuma tavalastega kollektiivis olema, aga samas oleneb lapsest. Mõni laps on väga-väga stressis juba ja kui ta ikka nutab ja nügib seal teisi, siis ta lihtsalt väga palju segab rühma tööd, teiste laste töö on häiritud. (staaž 38 aastat).

Nagu nähtub, paneb erivajadustega laste õpetamine tavarühmas proovile ka kogenud õpetaja, sest sõltumata diagnoosist on iga laps on erinev. Õpetajate sõnul ei vähendata erivajadusega lapse liitumisel sugugi alati rühma laste arvu, sageli ei ole erituge vajava lapse jaoks ka tugitöötajat. Abiks on raamatud ja koolitused, kuid enamasti peab õpetaja ise leidma lahenduse. Erivajadusega laps tavarühmas suurendab ka tegevuste kavandamisele ja dokumenteerimisele kuluvat aega. Üks vastaja selgitas ankeedis tüüpilist olukorda:

Individuaalne arenduskava - lastele tuleb teha palju pabereid. Meil praegu on kahjuks laste arv rühmas vähendamata ja puudub ka tugiisik - kolm erivajadustega last. (staaž 40 aastat).

Nii tähendab erivajadusega laps õpetajale lisanduvat asjaajamist, ent tegelik abi lapse aitamiseks sageli puudub. Vastajad nimetasid ka, et üha enam vajavad eritähelepanu diagnoosita lapsed - käitumishäirete ja väheste sotsiaalsete oskustega lapsed. Kuna lapsed on püsimatumad kui varem, peavad tegevused olema põnevad, et lapsi haarata. Kui lapsel on erivajadus, mis on lasteaeda tulekul jäänud märkamata, peab õpetaja suutma nii lapse erivajaduse kohta infot koguda kui ka vanemaid nõustada ja last aidata. Üks vastaja kirjutas:

Tuleb juurde erivajadustega lapsi. Kõigepealt tuleb erivajadus tõestada, siis taotleda appi eripedagoogi, tugiisikut, spetsialisti - abi taotlemine on raske. (staaž 2 aastat).

Mõned õpetajad märkisid, et vajaksid enam eripedagoogilist koolitust, kuna kohati tunnevad nad neist teadmistest puudust. Samuti mainiti erispetsialistide, nagu logopeedide, psühholoogide ja eripedagoogide puudumist lasteaias. Üks õpetaja rääkis:

Ma nii tunnen puudust esiteks sellisest kohast, kuhu saaks selle lapsega siis eraldi minna, kui mõni ikka seal tahab imelikult käituda. Et saaks teiste juurest nagu eemale minna. Ei ole sellist kohta, ei ole sellist inimest, kelle juurde teda näiteks viia. (staaž 27 aastat). 


\section{Muutused lastevanematega koostöös ja perede kasvatusväärtustes}

Õpetajad rõhutasid lastevanematega koostöö tähtsust, aga ka keerukust võrreldes varasemaga. Leiti, et vanemad on muutunud teadlikumaks ja nõudlikumaks, see aga põhjustab kohati pingeid õpetajate ja vanemate suhetes. Õpetajad selgitasid, et pidevatest koolitustest hoolimata ei suuda nad sageli vanemate nõudmistele vastata. Staažikad vastajad mainisid, et eriti keeruline on noortel õpetajatel, kellel on vähe kogemust ning kes ei oska ennast kehtestada. Märgiti, et vanemad nõuavad lasteaialt palju, kuid ise laste kasvatamisse samavõrd ei panusta. Üks vastaja kirjutas:

Vanemate suhtumine laste õigustesse, perede nõudmised lasteaiale on kasvanud, samas kui nende enda panus lapse kasvatamisse/öpetamisse väheneb. See ei kehti muidugi kõigi vanemate kohta. (staaž 8 aastat).

Mainiti ka muutusi laste koduses kasvatuses: see on palju vabam ja loomingulisem kui varem. Mõnel korral märgiti ka vanemate koolitusvajadust. Üks vastaja kirjutas:

Sisulisele tööle lastega jääb vähem aega. Väga palju rõhutakse lasteaia ja kodu koostööle, aga üha rohkem tundub, et lasteaed peab üksi töö ära tegema... Õpetaja on üha rohkem nii psühholoog, sotsiaaltöötaja, klienditeenindaja kui ka õpetaja. Üha rohkem on vaja tegeleda lapsevanemate ópetamisega kui lastega. (staaž 5 aastat).

Nagu nähtub, tunnevad õpetajad kohati, et lapsevanemad suhtuvad neisse kui teenindajaisse ja on liiga nõudlikud. Mitme vastaja arvates austavad lapsevanemad lasteaiaõpetajaid vähem kui varem, ameti maine on madal. Samas täheldasid vastajad pereprobleemide kasvu: varasemast enam lapsi elab üksikvanemaga või lahutatud vanematega peredes, üha enam on kärgperesid, kus samuti valitsevad keerukad suhted. Mainiti ka ühiskondlike vastuolude, nagu ainelise ebavõrdsuse ja vaesuse jõudmist lasteaeda, mis samuti mõjutab õpetaja tööd.

Kuigi vähe, oli vastanute seas ka neid, kelle arvates on koostöö lastevanematega väga hea - vanemad on koostöövalmid ja avatud ning soovivad rühma tegevustes osaleda. See näitab, et kõigi poolte ootustele vastav koostöö on võimalik.

\section{Muutused töökorralduses ja õpikeskkonnas}

Kolmanda tööd raskendava tegurina tõid vastajad esile uute ideede juurutamisega kaasnevad töökorralduslikud ja õpikeskkonnaalased muutused 
lasteaias. Eelkõige nimetati tööaja tegelikku pikenemist seoses üleminekuga nn pikalt päevalt (ühel päeval 10-12 tundi tööl, teine päev vaba) lühikesele päevale (iga päev 7 tundi tööl). Märgiti ka paberitöö mahu kasvu. Tööaja muudatuste kohta kirjutas üks vastaja:

Seoses tööaegade muutumisega on eriti vanemas eas inimesed väsinumad. Kuna sellele lisandub veel kirjalik töö arvuti taga, siis on läbipõlemise oht võrdlemisi suur. (staaž 2 aastat).

Õpetajate hinnangul võtab varasemast enam aega nii tegevuste kavandamine kui ka tehtu ning lapse arengu dokumenteerimine ja analüüsimine. Staažikad õpetajad mainisid, et nõukogude ajal oli töötempo rahulikum ning õpetaja tegelik töökoormus väiksem, lõuna ajal sai käia teistes rühmades ning tutvuda seal tehtavaga. Mainiti, et praegu on töötempo kiire, dokumenteerimine võtab palju aega ja energiat. Tööajal ei jõuta vajalikke pabereid täita, seda tuleb sageli teha väljaspool tööaega. Üks vastaja rääkis:

Paberitööd on juurde tulnud. Ja selleks ju eraldi tööaega ei ole. On ka asju, mis tuleb koju kaasa võtta. Näiteks kui ma täidan neid laste koolivalmiduse kaarte. (staaž 31 aastat).

Nn paberitöö on osa õpetajate sõnul keerulisemaks teinud ka asjaolu, et kui 2009. aastal kehtima hakanud määruses „Haridustöötajate tööaeg“ oli sätestatud, et õpetajate tööaeg on 35 tundi nädalas, millest õppe- ja kasvatustegevusele ehk otsesele tööle lastega peaks kuluma 30 tundi (seega jäi 5 tundi nädalas tegevuste kavandamisele, dokumenteerimisele ja koosolekutele), siis 2013. aasta määruses on üksnes mainitud, et õpetaja lühendatud tööaeg on 35 tundi nädalas. Seega otsustab lasteaia juhtkond, kuidas arvestada otseselt lastega tööle ja muude tööülesannete täitmisele kuluvat aega. Osa õpetajate sõnul tähendab see, et kõik tuleb ära teha ajal, mis ette nähtud tööks lastega. Kuna lapsed nõuavad õpetajalt aga täit tähelepanu, peab õpetaja tegevusi ette valmistama ning tehtut dokumenteerima oma vaba aja arvel. Üks vastaja kirjutas:

Paberite täitmise maht on suurenenud. Puudub tööaeg, millal korralikult valmistada ette järgmisi tegevusi. Kui seaduses on ettenähtud tööaeg päevas 7 tundi, siis reaalses elus pühendab õpetaja oma tööle 8-9 tundi päevas. (staaž 15 aastat).

Paberite täitmise all peeti silmas tegevuste kavandamist ja dokumenteerimist, laste arengu hindamist, arenguvestluste ettevalmistamist ja kirjapanemist, 
koolivalmiduskaartide täitmist, õpetaja eneseanalüüsi ning tööaruannete koostamist.

Kuna paljudes lasteaedades kasutatakse e-päevikut, on õpetajad pidanud arendama ka oma arvutioskusi. Samas raskendab õpetajate tööd nende kasutuses olevate arvutite aeglus. Üks vastaja kirjutas:

Kui töötada pidevalt ja kogu aeg arvutitega, mis on tigudestki aeglasemad, võtab lihtsalt tohutult palju aega - mida tegelikult võiks lastega tegelemisele kulutada. (staaž 27 aastat).

Samas mainis paar õpetajat, et infotehnoloogia on muutunud paremaks ning pigem kergendab tööd. Vastajad tunnustasid interneti võimalusi: kiiresti saab leida õppematerjale, teavitada lapsevanemaid ning suhelda omavahel. Õpetajate sõnul on oluliselt paranenud aineline õpikeskkond ning õppe- ja mänguvahendite valik ja headus. Õpetajad ei pea nii palju vahendeid ise koostama kui varem. Enamik intervjueerituid tunnustas valikuvabadust vahendite valimisel, see toetab neid nende töös.

\section{Muutused seadustikus, õppekavas ja õpikäsituses}

Vastajad rõhutasid, et seadustik, õppekavad ja nende aluseks olevad arusaamad lapse õppimisest ja õpetamisest on aja jooksul oluliselt muutunud. Vastajad pidasid varasemat õppekava üksikasjalikumaks, selles oli rohkem ettekirjutusi õppe- ja kasvatustegevuste korraldamiseks. Uus õppekava pakub õpetajale enam valikuvõimalusi tegevuste sisus ja korralduses, toetades seega õpetaja loovust. Üks vastaja rääkis:

Vanas õppekavas [nõukogudeaegses programmis] oli täpselt kirja pandud, mis vanuses, mida lastega ja kuidas täpselt teha. Nü̈̈d on uus riiklik óppekava, millest lasteaed on teinud oma õppekava. Mulle meeldib praegune õppekava, see laseb õpetajal rohkem mõelda. Õpetaja saab kasutada oma tugevusi. Praegused plaanid mulle meeldivad, need annavad mulle rohkem vabadust ja loovust. (staaž 35 aastat).

Enamiku intervjueeritute hinnangul on praegused seadustikus ja riiklikus õppekavas väljendatud kasvatus- ja õpetuspõhimõtted paremad võrreldes varasemaga, mil ei arvestatud kuigivõrd laste isikupäraga ning õpetajal oli vähe valikuvabadust. Mõnede vastajate hinnangul pakub töö lastega nüüd rohkem rahuldust, kuna see ei ole kellaajaliselt piiratud ning on seega loomingulisem ja paindlikum kui varem. 
Vastajad tunnustasid ka õpetaja rolli muutumist korralduste jagajast laste arengu suunajaks, võimalust kõiki tegevusi ja valdkondi õppes lõimida ning õpetajate arengu toetamist koolituste kaudu. Siiski mainisid vastajad, et nõukogudeaegne õppekava oli mugavam neile õpetajatele, kellele meeldib töötada kindla, etteantud raamistiku järgi ja kellele sobivad selged juhised. Üksikud õpetajad nimetasid, et oli kergem, kui töö eesmärgid, sisu ja meetodid olid ette kirjutatud, ning et praegu on õpetajal otsustamis- ja tegutsemisvabadust, samas ka kohustusi varasemast palju rohkem. Lasteaiasisese otsustusvabaduse suurenemisega on töö mõne õpetaja hinnangul muutunud kaootilisemaks. Üks vastaja kirjutas:

Erinevaid metoodikaid on palju - tiritakse siia-sinna, kõike tuleb justkui kasutada, rühmaruumi vastavalt kujundada (ruumipuudus), aru andapalju kasutate, kuidas kasutate, mis tulemused on jne. (staaž 10 aastat).

Vastajad leidsid, et kohati on ka lasteaia juhtidel raske pidevates uuendustes õiget suunda leida. Väljendati muret, et õpetajatöö lakkamatu ümberkorraldamise käigus kiputakse seni toiminud korraldusi lõhkuma ning õpetajatele peale suruma töövõtteid ja tegevusi, mis nende kasvatusväärtustega ei ühti. Laste käitumishäirete suurenemist seostas mõni vastaja otseselt nn uuenenud õpikäsitusega: lastele antavat liialt vabadust ning vähe kohustusi, mistõttu kannatab nende kohusetunne ja keskendumisvõime.

Kogenud õpetajad, kelle ametinimetus nõukogude ajal ja taasiseseisvusaja alguses oli kasvataja, pidasid oma staatuse seisukohalt väga oluliseks ja väärtuslikuks ametinimetuse muutust ópetajaks. Üks õpetaja selgitas ankeediküsimuse vabavastuses:

Lasteaiakasvatajast on saanud õpetaja ehk lihtsalt laste hoidjast on saanud ühiskonna silmis ka inimene, kes on oluline lapse arengu toetajana ja ópetajana. (staaž 25 aastat).

Teine vastaja selgitas intervjuus:

Ma arvan, et see nimetuse muutus on lihtsalt selle pärast, et kui me algul olime... kasvataja nimetus oli, see näitas noh... et lasteaed, aga nü̈̈d ópetaja nimetus, et see on nagu tasandatud kooliõpetajaga. (staaž 38 aastat).

Ametinimetuse muutus oli vastajatele oluline tõuge lasteaiaõpetaja erialal jätkamiseks. Nende hinnangul on sel olnud väärtuslik psühholoogiline mõju ka igapäevatöös suurenevate raskustega toimetulekule, kuna see võimaldab neil end samastada kooliõpetajatega. 
Teine oluline seadusmuudatus, mida enamik vastajaist pidas väärtuslikuks, oli lasteaiaõpetaja eriala haridusnõude tõstmine kõrghariduse tasemele. Vastajad selgitasid seda nii erialaselt kui ka üldiselt kõrghariduse kui haridustasemega seotud eelisena, sõltumata valdkonnast. Üks vastaja selgitas intervjuus:

Kõrgharidusega inimesed saavad ikka paljude asjadega paremini hakkama kui keskharidusega inimesed - esitlus või kellegi veenmine milleski või muu asi - seda oskust noortel [kórghariduseta ópetajatel] ei ole, et kui peab midagi kiiresti ära lahendama. (staaž 36 aastat).

Vastanute selgitustest nähtub, et riikliku õppekavaga sätestatud jm seadusmuudatustel on olnud lasteaiaõpetaja töö raskuse muutumisele vastandlik mõju. Ühest küljest suurendab muudatustega kuulutatud suurem vabadus ka töökoormust, teisalt ja mis veel olulisem, avaldab ametinimetuse ja erialaste haridusnõuete tõus tööd leevendavat psühholoogilist mõju: lasteaiaõpetajad tajuvad end ulatusliku tööalase vabadusega, kõrgelt hinnatud professionaalidena.

\section{Arutelu}

Uurimusega soovisime selgitada, millised on Eesti lasteaiaõpetajate hinnangud erialase töö raskuse muutumisele nende ametiaja jooksul ning kuidas lasteaiaõpetajad neid muutusi selgitavad. Eeldades teaduskirjanduse analüüsi põhjal, et paljud õpetajad tõepoolest täheldavad raskuse muutust, soovisime täpsemalt teada, millised üldised, rahvusvaheliselt tunnustatud käsituste ja mõistestiku abil kirjeldatavad suundumused iseloomustavad töö raskuse muutuste selgitusi. Uuringu tulemuste põhjal arutleme, milliseid võimalusi ja ohte võivad eri liiki muutused kaasa tuua lasteaiaõpetajate edasisele professionaliseerumisele ning millised võiksid olla edasised uurimissuunad ja alushariduspoliitilised algatused.

Meie uurimishuvi oli tingitud rahvusvaheliselt olulisest, ent seni ebapiisavalt uuritud asjaolust, et lasteaiaõpetajate hinnangud senistele professionaliseerumise algatustele on olnud vastukäivad. Prantsuse sotsioloogi Bourdieu mõistestikku ning sellel põhinevat professionalismi käsitust (Noordegraaf \& Schinkel, 2011; Schinkel \& Noordegraaf, 2011) on meile teadaolevalt lasteaiaõpetajate professionaliseerumise alases rahvusvahelises teadusperioodikas keskselt kasutatud vaid vähestel kordadel (Andrew, 2015; Jackson, 2017). Seega on nimetatud käsitus alushariduse kontekstis suhteliselt uus, samas aitab see aga hästi määratleda ja liigitada tegureid, mis on lasteaiaõpetajate hinnangul nende tööd kas raskemaks või kergemaks muutnud. 
Ankeetküsitluse olulisima tulemusena selgus vastuseks esimesele uurimisküsimusele, et sõltumata erialase töökogemuse pikkusest arvas ligikaudu kolmveerand vastajaist, et erialane töö on nende ametiajal muutunud raskemaks. Ülejäänutest enamik arvab, et töö raskus ei ole muutunud. Vaid 5\% arvab, et töö on muutunud kergemaks. See tulemus on kooskõlas paljudes maades täheldatuga, mille kohaselt lasteaiaõpetajate töö on viimaste kümnendite professionaliseerumise tulemusena muutunud raskemaks (Bradbury, 2012; Brown et al., 2015; Johansson, 2006; Osgood, 2012; Vlasov \& Hujala, 2016).

Vastusena teisele uurimisküsimusele selgus ankeediküsimuse vabavastustest ning intervjuudest, et raskemaks on muutunud eelkõige lasteaiaõpetaja igapäevatöö peamised aspektid - töö üha erinevamate ja enamate erivajadustega lasterühmadega, üha nõudlikumate ja iseteadlikumate lapsevanematega ning bürokratiseeruva töökorraldusega, samal ajal kui tegelik abi nende raskustega toimetulekuks sageli puudub. Ka see tulemus on kooskõlas teiste maade uurimustega, mille kohaselt õpilaskond mitmekesistub (Brown et al., 2015) ja lasteaiaõpetaja on üha enam kohustatud aru andma ametnikele ja lapsevanematele (Bradbury, 2012; Johansson, 2006; Osgood, 2012; Vlasov \& Hujala, 2016). Teisalt leidsid lasteaiaõpetajad, et nende tööd on kergendanud riikliku õppekavaga omistatud varasemast suurem vabadus oma tööd korraldada, samuti on psühholoogiliselt kergendavat mõju avaldanud varasemast kõrgemad haridusnõuded ning kasvataja ümbernimetamine õpetajaks.

Vastuseks kolmandale uurimisküsimusele ilmnes peamise üldistusena, et kui töö raskemaks muutumist selgitati eelkõige igapäevatöö aspektidega, siis tööd kergendavana toodi esile eelkõige seadusmuudatused lasteaiaõpetaja staatusesse puutuvas (kõrgem haridus, õpetaja ametinimetus, õppekavaga omistatud vabadus), millel on igapäevatööga vaid kaudne seos. Nimelt selles eristuses nähtub Bourdieu mõistestiku ning Schinkeli ja Noordegraafi (2011) professionalismi käsitluse asjakohasus: lisandunud on lasteaiaõpetaja professionaliseerumise välised tunnused - sümboolne kapital, mis annab lasteaiaõpetajatele staatuse võrdluses teiste professioonidega, eeskätt kooliõpetajatega. Nagu see on toimunud ja toimumas paljudes riikides (Katz \& Cain, 1988; Persson \& Tallberg Broman, 2015), on lasteaiaõpetajad ka Eestis suutnud saavutada kooliõpetajatega peaaegu võrdsed professionaalse staatuse tunnused. On oluline, et lasteaiaõpetajad seda saavutust väärtustavad ning näevad seda oma tööd kergendavamana - olgu või üksnes psühholoogiliselt, pigem kui igapäevases tööpraktikas. Teatava ettevaatlikkusega võib meie tulemuste põhjal väita, et sümboolse kapitali väärtuslik psühholoogiline mõju leevendab igapäevatöö raskemaks muutumist, mida enamik vastajaist ankeetküsitluses tervikuna väljendas. 
Kuigi nagu eespool kirjeldatud, ei soovi osa lasteaiaõpetajaid teatud põhjustel erialaste haridusnõuete tõusu (Jackson, 2017; Osgood, 2012), kinnitab hulk uurimusi mujalt maailmast ja Eestist siiski, et kõrgemal haridusel ja püsival erialasel enesetäiendamisel on lasteaiaõpetaja töö headusele suur tähtsus (Oberhuemer, 2015; Peeters, Sharmahd, \& Budginaite, 2018; Peterson et al., 2016; Veisson \& Kabaday, 2018; Whitington, Thompson, \& Shore, 2014). Sama võib öelda lasteaiaõpetaja teiste sümboolse kapitali osade kohta. Ent nimelt asjaolul, et tegemist on professionalismi kui sümboolse kapitali osadega ning need on seetõttu staatuse seisukohalt ihaldatavad, peitub nende kasutamises oht, mille üle arutleme vastusena neljandale, empiiriliste uurimisküsimuste vastustest tuletatud teoreetilisele uurimisküsimusele.

Nagu kirjeldatud, on sümboolne kapital suhteline ehk ilmneb üksnes võrdluses teistega, ning kuna seda on põhimõtteliselt üksnes piiratud kogus (kõik töötajad maailmas ei saa olla professionaalid, sest muidu kaotaks professionaali mõiste oma mõtte), on see võimuvõitluse aines (Schinkel \& Noordegraaf, 2011). Seega on sümboolne kapital suunatud teistele ühiskonnarühmadele teadvustamiseks ja tunnustamiseks. Lasteaiaõpetajate puhul kehtib nimetatu kõige otsesemalt kasvataja ametinimetuse õpetajaks muutmise kohta, samuti on väline nähtavus kahtlemata oluline lasteaiaõpetaja kõrghariduse nõude ja riikliku õppekavaga omistatud valikuvabaduse puhul. Samas on lasteaiaõpetaja igapäevatöö, selle sisu ja maht, tervikuna teada üksnes lasteaiaõpetajaile endile - ehkki eri ühiskonnarühmad (lapsed, lapsevanemad, juhtkond) näevad teatud sagedusega selle osi. Asjaolusid, mis selle töö raskemaks või kergemaks teevad, ei pruugi teised ühiskonnarühmad tervikuna üldse tajuda. Oht, millele püüame viidata, peitub seega professionaliseerumise näitajate kui sümboolse kapitali suhtes lasteaiaõpetaja igapäevatöö mahu ja sisuga. Kui haridusnõudeid tõstetakse, peaks lasteaiaõpetaja selle tulemusena suutma oma tööd paremini ja kergemini teha (Karila, 2012; Osgood, 2006), samuti olema rahul, sest tõuseb tema ühiskondlik staatus. Nagu meie tulemused näitavad, ei ole seda aga tervikuna toimunud. Sümboolse kapitali näitajad võivad seega osutuda vahendiks hariduspoliitikute käes, kes neid jagades juhivad tähelepanu kõrvale asjaolult, et lasteaiaõpetaja töö hõlbustamiseks ja kvaliteedi tõstmiseks on vaja ka muid, eelkõige majanduslikke vahendeid: et rühmad oleksid väiksemad, et oleksid kättesaadavad erivajadustega tegelevad spetsialistid ning kõrgem haridustase võimaldaks väiksemat koormust kasvõi aruandluse ehk paberitöö vähendamise võrra. Vajalike majanduslike vahendite loetelu võiks jätkata.

Hariduspoliitikute tõenäoliseks peamiseks motiiviks on mõistagi majanduslik kokkuhoid: lisada sümboolset kapitali ehk anda lasteaiaõpetajatele aumärk on odavam kui suurendada tegelikku palka või vähendada püsivalt töökoormust sama palga säilides. Hariduspoliitikute poolt võib selline sümboolse 
kapitali kasutamine sümboolse auhinnana olla nii teadvustatud kui ka teadvustamata. Sama võib olla lasteaiaõpetajatega - kuni selleni, et õpetajad ei mõista isegi, miks nad hoolimata lisanduvast sümboolsest kapitalist ikkagi oma tööga järjest raskemini hakkama saavad. Viimast nähtust iseloomustab tabavalt meie artiklis korduvalt viidatud Bradbury (2012) artikli pealkiri: „,,Tunnen end täiesti ebakompetentsena“: professionalism, poliitika ja lasteaiaõpetajad“.

Siinse uurimuse põhisõnumi võib kokku võtta tõdemusega, et lasteaiaõpetaja erialahariduse ja ametinimetuse ning alusharidusasutuse õppekava iga muudatusega peaks kaasnema kaalutlus: kas see on üksnes sümboolne muudatus, tõstmaks (halvimal juhul väärkasutamaks) lasteaiaõpetaja sümboolset kapitali, või kaasneb sellega ka tegelik muudatus lasteaiaõpetaja igapäevatöös, mis vähemalt pikemaajalises väljavaates võimaldab vähema vaevaga teha paremat tööd? Lasteaiaõpetajate professionaliseerumise sümboolseid näitajaid on vaja säilitada ja küllap edaspidi ka tõsta, aga lisanduv sümboolne kapital ei asenda majanduslikku kapitali, mida on vaja, et vähendada lasteaiaõpetajate tegelikku töökoormust, vabastada nad tarbetust ametlikust asjaajamisest (paberitööst) ning võimaldada asjatundjate pidev tugi laste lisanduvate erivajaduste ja lastevanemate nõudmistega toimetulekuks. Vastasel korral võibki lasteaiaõpetajal tekkida küsimus, milleks end koolitada ja arendada, kui erialane töö väliste asjaolude tõttu sellest hoolimata järjest raskemaks läheb.

\section{Tänuavaldused}

Artikkel on valminud projekti IUT18-2 „Õpetajate professionaalsuse ja professionalismi muutuv kontekst" toetusel. Täname uuringus osalenud õpetajaid.

\section{Kasutatud kirjandus}

Andrew, Y. (2015). Beyond professionalism: Classed and gendered capital in childcare work. Contemporary Issues in Early Childhood, 16(4), 305-321. https://doi.org/10.1177/1463949115616322

Bourdieu, P. (1993). The Field of Cultural Production. Essays on Art and Literature. Cambridge: Polity Press.

Bourdieu, P., \& Wacquant, L. (1992). An Invitation to Reflexive Sociology. Cambridge: Polity.

Bradbury, A. (2012). 'I feel absolutely incompetent': professionalism, policy and early childhood teachers. Contemporary Issues in Early Childhood, 13(3), 175-186. https://doi.org/10.2304/ciec.2012.13.3.175

Brock, A. (2014). What does professionalism mean to me? A. Brock (Ed.), The Early Years Reflective Practice Handbook (pp. 65-76). London: Routledge. 
Broström, S. (2017). A dynamic learning concept in early years' education: A possible way to prevent schoolification. International Journal of Early Years Education, 25(1), 1-13. https://doi.org/10.1080/09669760.2016.1270196

Brown, C. P., Weber, N. B., \& Yoon, Y. (2015). The Practical Difficulties for Early Educators Who Tried to Address Children's Realities in Their High-Stakes Teaching Context. Journal of Early Childhood Teacher Education, 36, 3-23. https://doi.org/10.1080/10901027.2014.996925

Clausen, S. B. (2015). Schoolification or early years democracy? A cross-curricular perspective from Denmark and England. Contemporary Issues in Early Childhood, 16(4), 355-373. https://doi.org/10.1177/1463949115616327

Goodson, I. F. (2013). Developing Narrative Theory. Life Histories and Personal Representation. London and New York: Routledge.

Gunnarsdottir, B. (2014). From play to school: are core values of ECDC in Iceland being undermined by 'schoolification'? International Journal of Early Years Education, 22(3), 242-250. https://doi.org/10.1080/09669760.2014.960319

HaridusSilm. (2015). Alusharidus. Külastatud aadressil http://www.haridussilm.ee.

Hsieh, H. F., \& Shannon, S. E. (2005). Three approaches to qualitative content analysis. Qualitative Health Research, 15, 1277-1288. https://doi.org/10.1177/1049732305276687

Jackson, J. (2017). Beyond the piece of paper: a Bourdieuian perspective on raising qualifications in the Australian early childhood workforce. European Early Childhood Education Research Journal 25(5), 796-805. https://doi.org/10.1080/1350293X.2017.1356575

Johansson, J.-E. (2006). Will there be Any Preschool Teachers in the Future? J. Einarsdottir \& J. T. Wagner (Eds.), Nordic Childhoods and Early Education: Philosophy, Research, Policy and Practice in Denmark, Finland, Iceland, Norway, and Sweden (pp. 43-69). Connecticut: Information Age Publishing.

Judge, H. (1998). Teacher Education. T. Husén, T., N. Postlethwaite, B. R. Clark, G. Neave (Eds.), Education: The Complete Encyclopedia (CD-ROM). Oxford: Elsevier Science Ltd.

Karila, K. (2012). A Nordic Perspective on early Childhood Education and Care Policy. European Journal of Education 47(4), 584-595. https://doi.org/10.1111/ejed.12007

Karlsson Lohmander, M. (2015). Bridging 'The gap' - linking workplace-based and university-based learning in preschool teacher education in Sweden. Early Years: An International Journal of Research and Development, 35(2), 168-183. https://doi.org/10.1080/09575146.2015.1025712

Katz, L. G., \& Cain, J. (1988). Early childhood education, teacher education for... T. Husen \& T. Neville Postlethwaite (Eds.), The International Encyclopedia of Education: Research and Studies, Vol. 3 (pp. 1487-1495). Oxford: Pergamon Press.

Locke, T., Vulliamy, G., Webb, R., \& Hill, M. (2005). Being a 'professional' primary school teacher at the beginning of the 21 st century: a comparative analysis of primary teacher professionalism in New Zealand and England. Journal of Education Policy 20(5), 555-581. https://doi.org/10.1080/02680930500221784 
Mikser, R., Niglas, K., Tuul, M., Veisson, M., \& Goodson, I. (2019). Academia undermining professionalism? The Estonian preschool teachers' views and expectations of teacher professionalism. P. Sivanes \& S. Garvis (Eds.), Teachers' and Families' Perspectives in Early Childhood Education and Care: Early Childhood Education and Care in the 21st Century, Vol. II. (pp. 58-70). Abingdon, Oxfordshire: Routledge Taylor \& Francis Ltd.

Mikser, R., Tuul, M., Veisson, M., Goodson, I. (2018). The place of theory and practice in preschool teachers' pre-service education: Estonian preschool teachers' evaluations in conditions of changing professionalism. C. Pascal, T. Bertram \& M. Veisson (Eds.), Early Childhood Education and Change in Diverse Cultural Contexts. (pp. 118-136). Abingdon, Oxon: Routledge, Taylor \& Francis Group.

Neudorf, E., Ugaste, A., Tuul, M., \& Mikser, R. (2017). Lasteaiaõpetajate uskumused seoses laste üldoskuste arendamisega riikliku õppekava alusel: lisaseletus lasteaia koolistumise põhjustele. Eesti Haridusteaduste Ajakiri 5(2), 54-79. https://doi.org/10.12697/eha.2017.5.2.03

Noordegraaf, M., \& Schinkel, W. (2011). Professional Capital Contested: A Bourdieusian Analysis of Conflicts between Professionals and Managers. Comparative Sociology 10, 97-125. https://doi.org/10.1163/156913310X514092

Oberhuemer, P. (2005). Conceptualising the early childhood pedagogue: Policy approaches and issues of professionalism. European Early Childhood Education Journal, 13(1), 5-16. https://doi.org/10.1080/13502930585209521

Oberhuemer, P., Schreyer, I., \& Neuman, M. J. (2010). Professionals in Early Childhood Education and Care Systems - European Profiles and Perspectives. Opladen: Barbara Budrich.

Oberhuemer, P. (2015). Parallel discourses with unparalleled effects: early years workforce development and professionalization initiatives in Germany. International Journal of Early Years Education 23(3), 303-312.

https://doi.org/10.1080/09669760.2015.1074560

Osgood, J. (2006). Deconstructing Professionalism in Early Childhood Education: resisting the regulatory gaze. Contemporary Issues in Early Childhood 7(1), 5-14. https://doi.org/10.2304/ciec.2006.7.1.5

Osgood, J. (2012). Narratives from the nursery: Negotiating professional identities in early childhood. London: Routlegde.

Payler, J. K., \& Locke, R. (2013). Disrupting communities of practice? How 'reluctant' practitioners view early years workforce from England. European Early Childhood Education Research Journal 21(1), 125-137. https://doi.org/10.1080/1350293X.2012.760340

Peeters, J., Sharmahd, N., \& Budginaite, I. (2018). Early childhood education and care (ECEC) assistants in Europe: Pathways towards continuous professional development (CPD) and qualification. European Journal of Education 53(1), 46-57. https://doi.org/10.1111/ejed.12254

Persson, S., \& Tallberg Broman, I. (2015). Professionalization processes and gender issues - the establishment of ECEC workforce in Sweden. V. Campbell-Barr \& J. Georgeson (Eds.), International Perspectives on Early Years Workforce Development. (pp. 56-68). Norwich: Critical publishing. 
Peterson, T., Veisson, M., Hujala, E., Härkönen, U., Sandberg, A., Johansson, J., \& Kovacsne Bakosi, E. (2016). Professionalism of Preschool Teachers in Estonia, Sweden, Finland and Hungary. European Early Childhood Education Research Journal 24(3), 136-156. https://doi.org/10.1080/1350293X.2015.1120529

Pruit, J. C. (2019). Between Teaching and Caring in the Preschool: Talk, Interaction and the Preschool Teacher Identity. London: Lexington Books.

Raud, R. (2013). Mis on kultuur? Sissejuhatus kultuuriteooriatesse. Tallinn: TLÜ Kirjastus.

Ruus, V.-R., \& Mikser, R. (2013). Õppekava. Mikser, R. (Koost), Haridusleksikon (257-264). Tallinn: Eesti Keele Sihtasutus.

Ryan, S., \& Gibson, M. (2016). Preservice Early Childhood Teacher Education. L. J. Couse \& S. L. Recchia (Eds.), Handbook of Early Childhood Teacher Education (pp. 195-208). New York, NY: Routledge, Taylor \& Francis Group.

Schinkel, W., \& Noordegraaf, M. (2011). Professionalism as Symbolic Capital: Materials for a Bourdieusian Theory of Professionalism. Comparative Sociology 10, 67-96. https://doi.org/10.1163/156913310X514083

Tight, M. (2002). Key Concepts in Adult Education and Training. London: RoutledgeFalmer.

Torm, M. (2011). 170 Years of Development in Estonian Preschool Institutions: Historical Trends in Preschool Education. In M. Veisson, E. Hujala, P. K. Smith, M. Waniganayake, \& E. Kikas (Eds.), Global Perspectives in Early Childhood Education Diversity, Challenges and Possibilities (pp. 81-104). Frankfurt am Main: Peter Lang Verlag.

Van Laere, K., Peeters, J., \& Vandenbroeck, M. (2012). The education and care divide: The role of the early childhood workforce in 15 European countries. European Journal of Education, 47(4), 527-541. https://doi.org/10.1111/ejed.12006

Vapper, T. (2015). Kui ei meeldi, mine ära. Opetajate Leht, 15, 2.

Veisson, M. (2017). ECEC Workforce Profile - Estonia. In P. Oberhuemer and I. Schreyer (Eds.), Workforce Profiles in Systems of Early Childhood Education and Care in Europe. www.seepro.eulcountryreports $\backslash$ estonia

Veisson, M., \& Kabaday, A. (2018). Exploring the Preschool Teachers' Views on Professionalism, Quality of Education and Sustainability. International Journal of Teacher Education of Sustainability, 20(2), 5-18.

https://doi.org/10.2478/jtes-2018-0011

Veisson, M., \& Mikser, R. (2013). Alusharidus. Mikser, R. (Koost), Haridusleksikon. (36-42). Tartu: Eesti Keele Sihtasutus.

Whitington, V., Thompson, C., \& Shore, S. (2014). 'Time to ponder': professional learning in early childhood education. Australasian Journal of Early Childhood, 39(1), 65-72. https://doi.org/10.1177/183693911403900109

Vlasov, J., \& Hujala, E. (2016). Cross-cultural interpretations of changes in early childhood education in the USA, Russia and Finland. International Journal of Early Years Education, 24(3), 309-324.

https://doi.org/10.1080/09669760.2016.1189812 


\title{
Preschool teachers' evaluations and explanations to changes in their work related difficulties: professionalisation as a symbolic capital
}

\author{
Rain Miksera ${ }^{a}$, Marika Veisson ${ }^{\text {a }}$, Maire Tuul ${ }^{a}$, Tiia Õun ${ }^{\text {al1 }}$, Kerstin Kööp ${ }^{a}$ \\ ${ }^{a}$ School of Educational Sciences, Tallinn University
}

In Estonia, the professional qualifications of preschool teachers have been raised in order to enhance the quality of preschool education. This policy has not been popular with all preschool teachers. Some welcome the changes, seeing them as a recognition of the preschool teacher as a true professional. Others see the rising requirements making their work more difficult and placing them increasingly accountable to external groups, such as administrators and parents (Bradbury 2012; Jackson 2017; Vlasov \& Hujala 2016).

In this study, we aimed at elucidating the Estonian preschool teachers' evaluations and explanations of the changes to the difficulty of their work over the period of their tenure. We also aimed at a preliminary categorisation of the aspects that have made preschool teachers' work more difficult or easier, and to give policy recommendations and hints for further research on the professionalisation of preschool teachers.

First, we give an overview of the concept of professionalism and professionalisation that we use as the conceptual basis for our study. This conceptualisation was first launched by the French sociologist Pierre Bourdieu (Bourdieu \& Wacquant, 1992) and has been further developed by Willem Schinkel and Mirko Noordegraaf (2011). Following Bourdieu, Schinkel and Noordegraaf observe professionalism as a form of symbolic capital, i.e. a capital containing social and cultural qualities that enable a professional group to establish its status in relation to other social groups. Schinkel and Noordegraaf (ibid.) consider professionalisation as a dynamic concept that expresses the relationality and instability of professionalism issues at any given moment and the continual struggle between, and within, different social fields for professionalisation-related status and symbolic capital.

By briefly overviewing the historical professionalisation of the preschool field in relation to the field of general education (Katz \& Cain, 1988; Persson \& Tallberg Broman, 2015), we next demonstrate how the professionalisation of the preschool field has been a complex struggle related to the symbolic capital and status, thus explainable by the Bourdieusian terminology. Over the last

School of Educational Sciences, Tallinn University, Narva Street 25, 10120 Tallinn, Estonia; tiiaoun@tlu.ee 
decades, the field has become more regulated (including the establishment of the national curriculum for preschool institutions), and the formal qualification criteria have risen so that they are now comparable to those of schoolteachers (Oberhuemer et al., 2010). Recently, similar developments have characterised the field of preschool education in Estonia (Mikser et al., 2018; Mikser et al., 2019). In terms of the added symbolic capital of the preschool teachers' profession, the struggle has been successful, since the quality standards in this field are now comparable to those applied to the schoolteachers (Van Laere et al., 2012; Neudorf et al., 2017).

Our empirical study included a written questionnaire focused on the respondents' evaluation of how the difficulty of their work has changed over the period of their tenure. We asked them to mark the most appropriate statement from the list below: (1) the work has become substantially more difficult; (2) the work has become somewhat more difficult; (3) the difficulty of the work has not changed; (4) the work has become somewhat easier; (5) the work has become substantially easier. Below the list, we asked the respondents to comment on their responses in a free form. 628 preschool teachers across Estonia answered the question, out of whom 420 (66.9\%) added a comment. The second phase of the study included a life history interview with 15 experienced teachers (out of the 628) who had agreed to be interviewed.

Assuming that preschool teachers' views differed depending on their length of service, we divided the respondents to the written questionnaire into three groups according to the length of their professional experience: (1) working experience up to 8 years - have worked only according to the latest version of the national curriculum for preschool institutions; (2) working experience from 9 to 24 years - started working after the Soviet period; (3) working experience of 25 or more years - having worked during and after the Soviet period. Other socio-demographic data generally corresponded to the overall population of preschool teachers in Estonia (only 3 of the respondents were male, since the proportion of men among preschool teachers in Estonia is small).

In all the groups, roughly three quarters of the respondents evaluated the work as having become substantially or somewhat more difficult over the period of their tenure. Having obtained that knowledge, we then categorised the respondents' comments into three categories that represented the main reasons why the work has become more difficult: these were the changes related to (1) children; (2) parents; and (3) work organisation. Additionally, the fourth category emerged from the responses of those with more than 8 years' experience: (4) changes in legislation, curricula and approach to learning. The first category involved the respondents' general opinion that the students' 
contingent (i.e. children) has become more diverse, including more children with special needs, whereas there is often no adequate support available from staff members with relevant special qualifications. The second category involved the respondents' comments that parents have become more demanding and self-conscious, often treating preschool teachers as waiters but not sufficiently contributing to educating their children themselves. The third category involved the alleged increase of bureaucratic duties or 'paperwork', meaning that written reports and assessments are required much more than before. This finding indicates that the trust in the professional competence of preschool teachers has decreased - higher professional preparation requirements have paradoxically been accompanied with more accountability.

In the face of these negative developments, our fourth category revealed that the respondents were very positive about the rise of their qualification requirements to the higher education degree and, in particular, about the renaming of their profession from the 'educator' (Est. kasvataja) to 'teacher', specifically because the latter name defines them as equal to schoolteachers. The respondents also expressed their satisfaction with the degree of freedom of professional decision-making granted them within the national curriculum for preschool institutions and other legislative documents.

To conclude, the answer to our first research question was that nearly three quarters of the preschool teachers found their work becoming more difficult over the period of their tenure. The answer to our second research question i.e. the reasons for their work having become more difficult, were manifold and can be classified into distinct categories. These reasons were substantially related to the everyday working practices of the teachers: dealing with the children particularly those with special needs, with the increasing demands of the parents, and with increasing bureaucracy. However, the aspects that the respondents found as facilitating their work were related to the status-bound factors that were more distant from their daily working practices, such as the legislative changes to raise their qualification requirements, to rename the professionals from educators to teachers, and to increase preschool teachers' freedom of decision-making as stated in the national curriculum and other legislative acts. This contradistinction, i.e. the aggravating versus mitigating factors can be regarded as the response to our third research question.

Our most important policy recommendation resulting from the study (i.e. the answer to our fourth research question) is the need to supplement each policy change in the preschool education with material resources that would adequately correspond to the presumed rise in the status of the preschool teachers' profession. This is most necessary for supplying the symbolic capital 
requested by the preschool professional with the necessary economic capital for enabling the field professionals to perceive their professionalism as enhanced and recognised by other professional, public and political interest groups.

Keywords: professionalisation, changes, teacher, preschool education 